\title{
Ecological network analysis in modeling of plant population dynamics
}

\author{
Grażyna Laska, Aneta Sienkiewicz \\ Department of Environmental Protection and Management, Białystok Technical University, \\ Wiejska 45a St, 15-351 Białystok, Poland; \\ *e-mail: a.sienkiewicz@pb.edu.pl
}

Received: 7 November 2017 / Accepted: 29 January 2018

\begin{abstract}
One of the most popular tools used in the process of modeling are ecological networks. Population dynamics of threatened plant species - Pulsatilla patens (L.) Mill. and commonly occurring taxon - Carex digitata L., was modeled using the package STELLA. The population of $P$. patens was studied in the years 2009-2011, at 16 sites, while the population of $C$. digitata was observed in the years 1987-2015, at the two sites in the natural and secondary oak-hornbeam forest Tilio cordatae-Carpinetum betuli Tracz. 1962 in the Supraśl Forest Division, Knyszyńska Forest. The input parameters for model construction were changes in the number of individuals and calculated on their basis birth and death rates. The proposed mathematical model of population dynamics implies that the probability of $P$. patens becoming a threatened species, evaluated on the basis of changes in the number of individuals is small, however it increases for $C$. digitata (in particular in the anthropogenically disturbed community). The results of simulations show that $P$. patens makes dynamically developing population characterized by an increase in the number of individuals with time in the period studied, disregarding the effect of natural and anthropogenic disturbances. In both $C$. digitata communities studied, a decrease in the number of individuals in the period studied is noted, and the rate of the decrease is much higher in the anthropogenically disturbed community, which means that the population is dynamically ageing.
\end{abstract}

Key words: population models, STELLA modeling, Pulsatilla patens (L.) Mill., Carex digitata L., probability of extinction, guidelines for protection.

\section{Introduction}

Over the past two decades, ecological models have become important tools for aiding decisions related to the conservation of biodiversity. Ecological models are frequently used to predict and assess the outcomes of conservation measures and ecosystem management strategies (Frank \& Wissel, 2002; Leslie et al., 2003). Different ecological model types have been used, depending on the aim of modeling, e.g. species-distribution models to predict the future distribution of species (Attorre et al., 2013), individual species models to identify threatened plant species hotspots (Parviainen et al., 2009), model simulations to impact cli- mate change on ecosystems (Fang et al. 2013) and models of population dynamics of endangered and threatened species (Beissinger \& McCullough, 2002; Morris \& Doak, 2002).

One of the most popular tools used in ecological modeling are networks. Networks are well suited for analysis of many types of ecological data (Raymond \& Hosie, 2009). Complex structures of inter-related elements are pervasive in natural systems (Aloy \& Russell, 2004; Green et al., 2005; Proulx et al., 2005) and network-based methods can provide an intuitive framework for understanding these systems. The importance of considering the overall ecosystem context when investigating elements of that ecosystem has long been recognized in the ecological 
sciences, but has been given recent re-emphasis (Jordán \& Scheuring, 2004).

Network applications in ecology have received a recent surge of popularity (Green et al., 2005; Proulx et al., 2005). Networks offer insights into system-level properties that arise from the structure of the network, and which are not evident from the properties of the entities alone. Network-based methods can facilitate the analytical integration of an overall ecosystem with the dynamics of its individual elements (Jordán \& Scheuring, 2004). Topology can provide information on the networks functioning and response to change (Jordán, 2001; Dambacher et al., 2003; Proulx et al., 2005). Moreover, the model could respond to the needed theoretical formalization of decisionmaking in ecosystem-based management (Rooney, 2001; Reynolds, 2005; Jensen et al., 2009).

Artificial neural networks (ANNs) are one of the easiest networks to understand, so they have been most commonly used in ecology. However, they are sensitive to composition of the training data set and to initial network parameters. Also, they are perceived as black box models (Özesmi et al., 2006). STELLA is a popular tool for dynamics modeling, which helps to put together conceptual diagrams and converts them into numerical computer models (Naimi \& Voinov, 2012). It permits finding relationships that can be mathematical, logical, graphical or numerical (Costanza \& Voinov, 2001). An increasingly popular method of modelling of uncertain and complex domains such as ecosystems and environmental management are Bayesian networks (BNs). They facilitate learning about causal relationships between variables based on probability distributions of the analyzed variables (Uusitalo, 2007). They offer the possibility of simulation and optimization of the levels of modeled factors, which gives background for making decisions supporting correct functioning of the natural environment (Łaska \& Sienkiewicz, 2015).

The purpose of this study was to construct mathematical models of population dynamics of a threatened plant species - Pulsatilla patens (L.) Mill. and a common taxon Carex digitata L., using the commercial available package STELLA. The specific objectives of this study were to: (1) develop dynamic models for estimating the probability of extinction of analyzed plant populations, (2) calibrate the models using available experimental data and (3) apply the models for assessment of the risk and development of guidelines for the protection of these populations.

\section{Study area}

The study of $P$. patens and $C$. digitata populations was conducted in north-eastern Poland, in the Supraśl Forest Division, Knyszyńska Forest. This is the forest area of approximately $17,439.94$ ha located in the central part of the
Forest (Forestry Commission Forest Management Plan Supraśl, 2006-2015) which belongs to the Natura 2000 network (Łaska, 2006, 2009). The population of P. patens was studied in the years 2009-2011, at 16 study sites (Laska, 2010) and the population of $C$. digitata was studied in the years 1987-2015, at the two sites of natural and secondary oak-hornbeam forest Tilio cordatae-Carpinetum betuli Tracz. 1962 (Łaska, 2012).

\section{Study species}

Pulsatilla patens (L.) Mill. (Ranunculaceae) is a threatened plant species in Europe, listed in the Annex II of European Union Habitats Directive (92/43/ETY) (European Communities, 2004) and in Appendix I of the Bern Convention (Journal of Laws 1996, no. 58, item 263, 264). In Poland, $P$. patens has been a strictly protected species since 1958 , it requires active protection (Journal of Laws, 2014, item 1409) and is classified to be protected within the program Natura 2000 (Journal of Laws, 2005, no. 94, item 795). In the "Red List of Vascular Plants in Poland" it is classified as critically endangered (E category) (Zarzycki \& Szeląg, 2006) and in the "Red Data Book of Poland", it is listed as endangered (EN) species (Kaźmierczakowa et al., 2014).

Carex digitata L. (Cyperaceae) is a commonly occurring in the temperate zone of Europe and Asia, mesotrophic oak-hornbeam species, growing most often in the shady deciduous forests (Matuszkiewicz, 2001; Zarzycki et al., 2002), it also occurs in other habitats of diversified natural communities (in mixed deciduous and coniferous forests). C. digitata also appears in the anthropogenically disturbed communities (on the clear-cuts, in pine cultivations, in the secondary forest communities with an artificial pine stand) (Łaska, 2006, 2012).

\section{Methods}

\subsection{Population dynamic model built with STELLA}

Mathematical models of population dynamics of $P$. patens and $C$. digitata were built using the stock and flow model software (STELLA II 3.0.7) with an icon based interface and availability of array functions (Costanza \& Voinov, 2001; High Performance Systems Inc., 2002). After Doerr (1996) it is assumed that the system dynamics is a concept that considers the dynamic interaction between the elements of the studied system and can help to understand their behavior over time, build models, identify how information feedback governs the behavior of the system and develop a strategy for better management of the studied system. 
The initial parameters for construction of the population dynamics model were the changes in the number of individual plants of $P$. patens and $C$. digitata, counted in defined time intervals. In the mathematical model it was assumed that a population grows exponentially according to the birth rate and dies according to the death rate. It was also assumed that the size of a population determined by the birth and death rates (Falińska, 2012) does not depend on the natural (biotic and abiotic) and anthropogenic disturbances. The estimation of the probability of population extinction over the next 10 years is made assuming that birth rate is constant, while the death rate depends on the nominal death rate assumed in the model, normal distribution with a mean of nominal death rate and statistical parameters assumed as its arguments (mean and standard deviation) (Hannon \& Ruth, 1997). Also the mean size of population was taken into account, defined as the ratio of the total number of individuals in a certain time interval to that in the assumed period of counting. The dynamic simulation model was developed using a time step of 0.25 years and the Euler's integration method.

\section{Results}

\subsection{Dynamics of population Pulsatilla patens and Carex digitata}

On the basis of the counted numbers of $P$. patens individuals, the size of its population was found to increase from 165 in 2009 to 267 in 2011. At nine sites the number of individuals was observed to increase, at 5 it decreased, while at 2 it remained the same. The highest number of $P$. patens individuals in 2009 was at site 1 at which 82 plants were noted, while in 2011 at the same site the number of indi- viduals grew by $89 \%$. In 2011 only at two sites, number 8 and 13, no plants of this species were noted, (Fig. 1) (Easka \& Sienkiewicz, unpubl. data). On the basis of this data the calculated birth rate for $P$. patens population is $26 \%$, while the death rate is $7 \%$.

The number of $C$. digitata individuals changed slightly in the population from the natural oak-hornbeam community and declined in the population from the anthropogenically disturbed community. At the beginning of the observation period (1987), a greater number of $C$. digitata individuals in the population was observed at the anthropogenically disturbed site (378 individuals) than in the natural oak-hornbeam community (63 individuals) (Łaska, 2012). After 29 years (2015), in the natural oak-hornbeam community, the number of individuals remained relatively stable (from 63 to 55 individuals) and at the anthropogenically disturbed site it declined (from 378 to 96 individuals) (Łaska, unpubl. data). The calculated birth rate for C. digitata population from the natural oak-hornbeam community was $1.5 \%$ at the death rate $2.1 \%$, while for the population from the anthropogenically disturbed community it was $0.5 \%$ at the death rate $3 \%$.

\subsection{Model of population dynamics Pulsatilla patens and Carex digitata}

The structure of the model describing the population dynamics of $P$. patens and $C$. digitata is shown in Figure 2. The model consists of two stocks (rectangles): Population and Sum population and eight converters (circles): Births, Deaths, Death rate, Nominal death rate, Death rate distribution, Death rate distribution control, Current population, Average population size. The model contains three flows and ten storage connections needed for the network analysis. Parameters of this model are determined by the func-

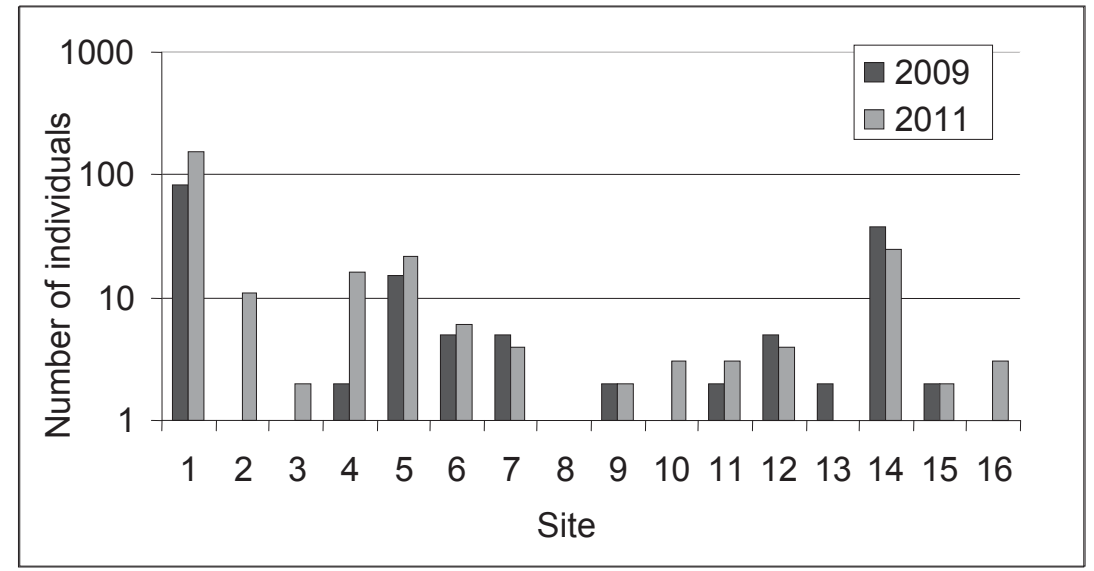

Figure 1. Dynamics of the Pulsatilla patens (L.) Mill. population in the Supraśl Forest Division, Knyszyńska Forest (Łaska \& Sienkiewicz, unpubl. data) 
tions defined in Figure 2. Their analysis permitted evaluation of the probability of extinction of the analyzed plant populations.

On the basis of the simulation performed for the assumed birth and death rates, the size of $P$. patens population was found to increase over the period of 10 years for which the calculation was made (Fig. 3). The population size increased by $24 \%$, at the mean number of individuals for the period of 10 years of 273 and the nominal death rate of -0.18 (Table 1). As follows from the results, up to the fourth year of the simulation the rate of population increase is relatively constant, in the longer time period events of periodical decrease in the number of individuals are noted, in particular in the fifth and eighth years of simulation.

According to the simulation results for P. patens population, at the low death rate with respect to the birth rate, the probability of the population becoming endangered because of the decrease in population size is very small. The periodical decrease in the number of individuals does not exceed the population size assumed as input datum in the
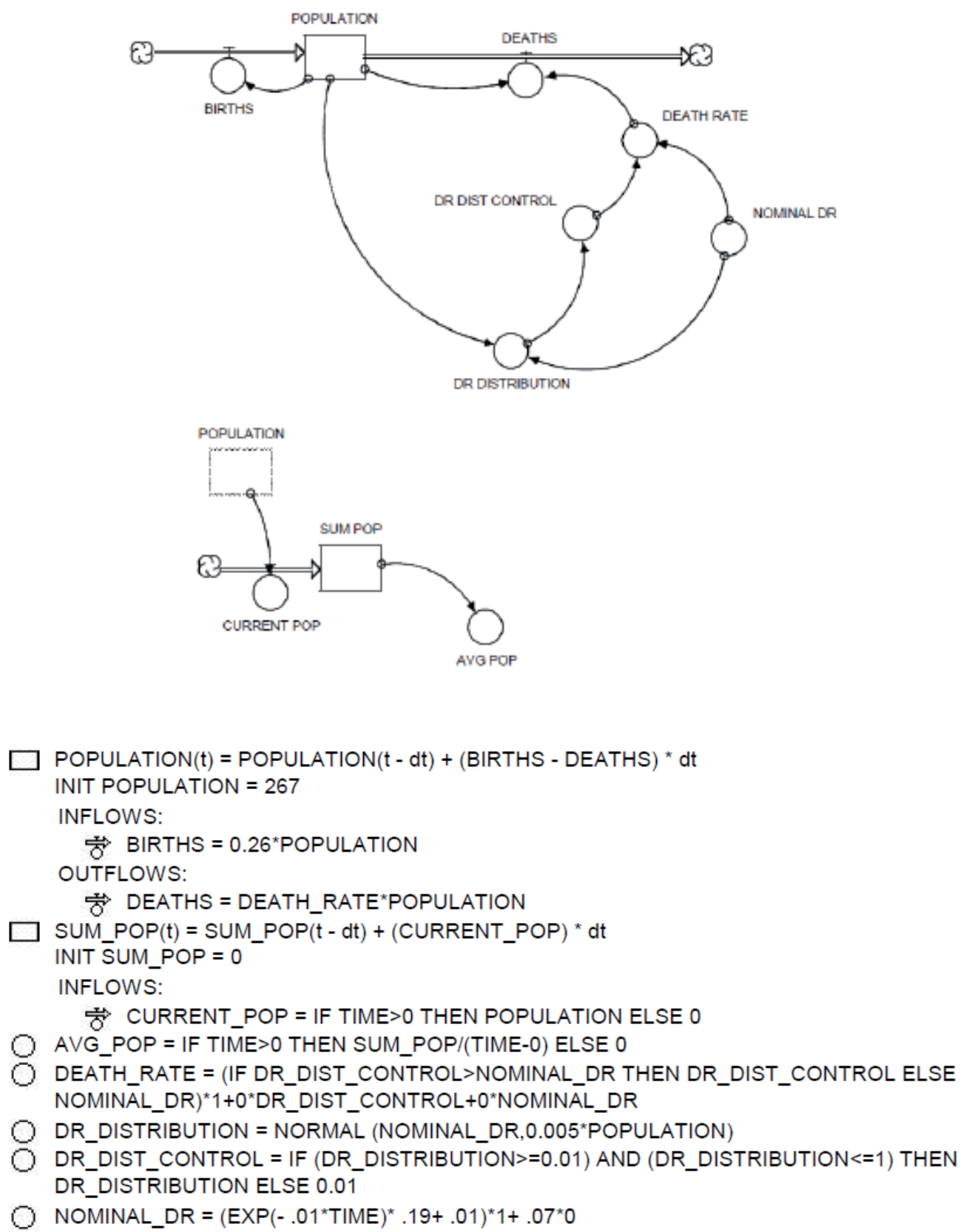

Figure 2. The structure of mathematical model of population dynamics of Pulsatilla patens (L.) Mill. and Carex digitata L. and the functions describing the model parameters 


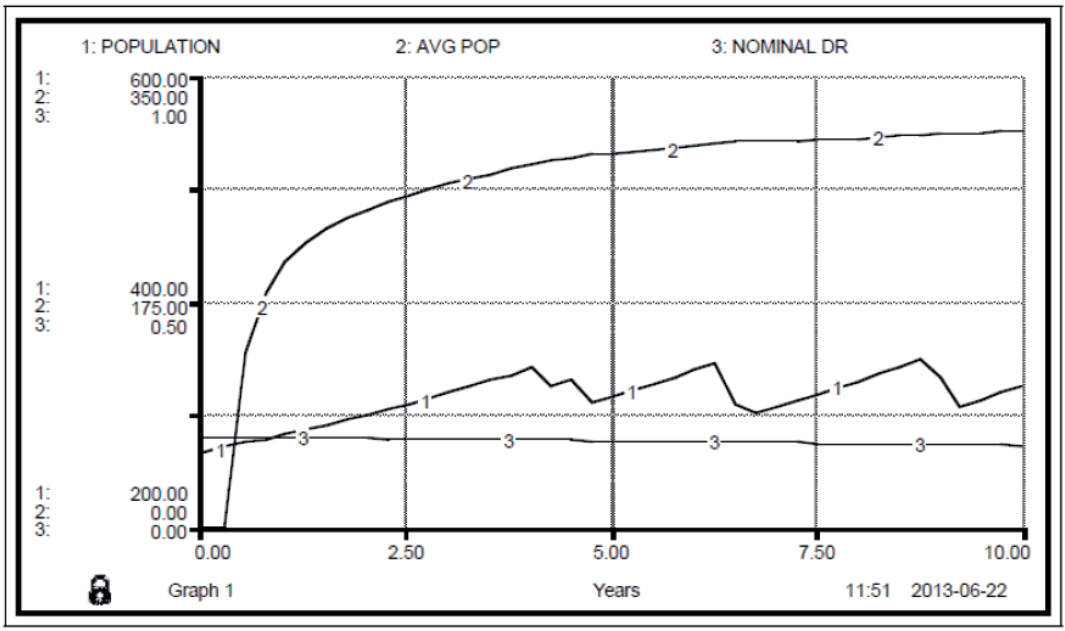

Figure 3. Simulation of the population of Pulsatilla patens (L.) Mill. population size dynamics, mean population size and nominal death rate for the 10 year period of calculations

\begin{tabular}{|r|r|r|r|}
\hline Years & POPULATION & \multicolumn{1}{|l|}{ AVG POP } & NOMINAL DR \\
\hline 0 & 267.00 & 0.00 & 0.20 \\
\hline 1 & 283.02 & 0.00 & 0.20 \\
\hline 2 & 300.54 & 141.51 & 0.20 \\
\hline 3 & 319.70 & 194.52 & 0.19 \\
\hline 4 & 340.68 & 225.81 & 0.19 \\
\hline 5 & 277.68 & 248.79 & 0.19 \\
\hline 6 & 296.92 & 253.60 & 0.19 \\
\hline 7 & 318.02 & 259.79 & 0.19 \\
\hline 8 & 287.19 & 267.07 & 0.19 \\
\hline 9 & 308.62 & 269.30 & 0.18 \\
\hline Final & 332.18 & 273.24 & 0.18 \\
\hline
\end{tabular}

Table 1. Pulsatilla patens (L.) Mill. population size, mean population size and nominal death rate in particular years of the 10 year simulation period

model. It means that disregarding the effects of natural and anthropogenic disturbances, the population of $P$. patens is dynamically developing with the number of individuals increasing with time.

The simulation of population dynamics for $C$. digitata from the natural oak-hornbeam site and the anthropogenically disturbed site, performed for the assumed birth and death rates for the 10 year period, proved a decrease in the population size (Figs 4a, b). In the natural oak-hornbeam community the decrease in number of this species individuals decreased by $20 \%$, at the mean population size of 44 individuals and the nominal death rate of -0.02 (Table 2a). At the anthropogenically disturbed site, the decrease reached $82 \%$, at the mean population size of 24 individuals and the nominal death rate of -0.03 (Table $2 b$ ). The rate of $C$. digitata population size decrease was much greater in the anthropogenically disturbed community than at the natural oak-hornbeam site.

According to the results of simulation for $C$. digitata population, at the high death rate with respect to the birth rate, the probability of the population becoming endangered increases. It is particularly pronounced for the population from the anthropogenically disturbed community, in which the greatest changes in population size (from 378 to 96 individuals) were noted at the lowest birth rate $(0.05 \%)$. For $C$. digitata, at both study sites a decrease 
a)

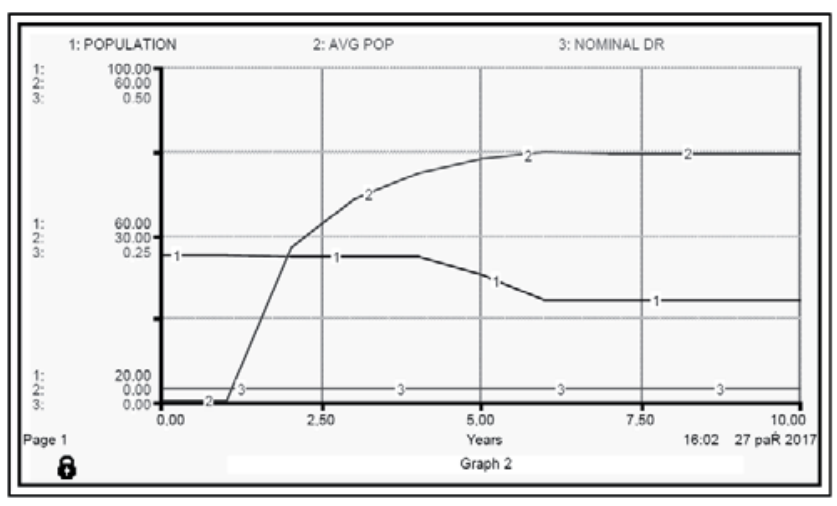

b)

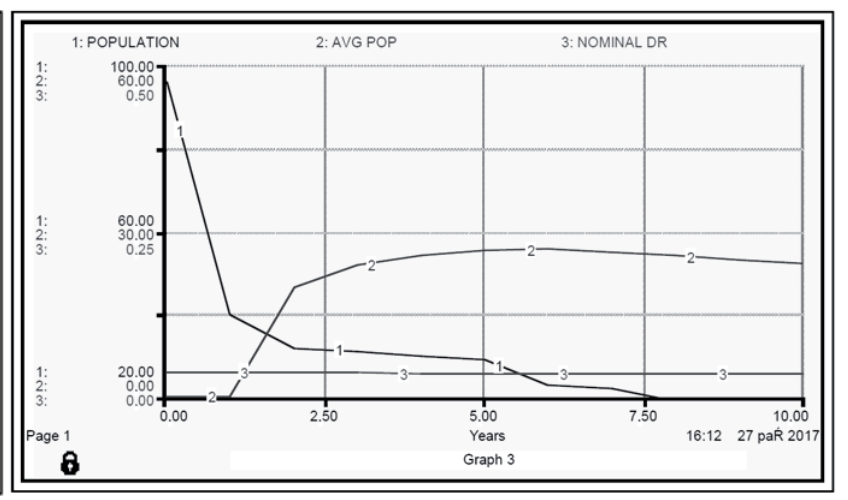

Figure 4. Simulation of Carex digitata L., population size, mean population size and nominal death rate for the 10 year period of calculations, for a) the natural oak-hornbeam community, b) the anthropogenically disturbed community

in the number of individuals was observed in the 10 year period of study, which indicates that it makes a dynamically ageing population.

\section{Discussion}

Ecological network analysis is an important tool to understand the whole-system interactions. The edges in the network show direct relationships between entities, and so the network explicitly depicts the local structure within the data, allowing the topology of the system as a whole to emerge from the individual relationships.

The explicit characterization of relationships by edges in a network has potential advantages for the visual representation of complex data, but perhaps more interestingly, allows subsequent exploration and analyses to focus on the relationships themselves (Raymond \& Hosie, 2009). More- over, networks can be used to integrate ecological data with other types of data such as economic (Janssen et al., 2006), not merely in visual syntheses but in analytical integrations that allow the effects of human impacts on ecosystems to be explored (Dambacher et al., 2003; Fath, 2004; Rooney et al., 2006; Dambacher \& Ramos-Jiliberto, 2007).

However, Lek (2007) has reported that being simplified representations of the reality, the simulated ecological models can never be the same as the real nature, i.e. their results are somewhat uncertain. The uncertainty of an ecological model is caused by both the lack of knowledge (i.e. data imperfection) and the variability of models and parameters (models' sensitivity). Data may contain errors that result from either sampling, measurement or estimation mistakes (Regan et al., 2002). Uncertainty analysis in the ecological models implies the identification of errors, inexactness, imperfection and unreality in the models (Li \& Wu, 2006; Wu et al., 2006). The considerations of uncertainty in the

Table 2. Carex digitata L., population size, mean population size and nominal death rate in particular years in particular years of the 10 year simulation period in a) the natural oak-hornbeam community, b) the anthropogenically disturbed community

a)

\begin{tabular}{|r|r|r|r|}
\hline Years & POPULATION & AVG POP & NOMINAL DR \\
\hline & 55.00 & 0.00 & 0.02 \\
\hline 1 & 54.95 & 0.00 & 0.02 \\
\hline 2 & 54.50 & 27.47 & 0,02 \\
\hline 3 & 54.45 & 36.48 & 0.02 \\
\hline 4 & 54.41 & 40.97 & 0.02 \\
\hline 5 & 50.06 & 43.66 & 0.02 \\
\hline 6 & 43.90 & 44.73 & 0.02 \\
\hline 7 & 43.88 & 44,61 & 0.02 \\
\hline 8 & 43.85 & 44.52 & 0,02 \\
\hline 9 & 43.83 & 44.44 & 0,02 \\
\hline Final & 43.80 & 44.38 & 0.02 \\
\hline & & &
\end{tabular}

b)

\begin{tabular}{|r|r|r|r|}
\hline Years & POPULATION & AVG POP & NOMINAL DR \\
\hline 0 & 96.00 & 0.00 & 0.04 \\
\hline 1 & 39.58 & 0.00 & 0.03 \\
\hline 2 & 31.53 & 19.79 & 0.03 \\
\hline 3 & 30.60 & 23.70 & 0.03 \\
\hline 4 & 29.71 & 25.43 & 0.03 \\
\hline 5 & 28.84 & 26.28 & 0.03 \\
\hline 6 & 22.57 & 26.71 & 0.03 \\
\hline 7 & 21.93 & 26.12 & 0.03 \\
\hline 8 & 18.50 & 25.59 & 0.03 \\
\hline 9 & 17.98 & 24.81 & 0.03 \\
\hline Final & 17.48 & 24.12 & 0.03 \\
\hline
\end{tabular}


ecological models have lately increased for ecological research areas, such as risk assessment of species (Regan et al., 2003) or biological conservation (Wintle et al., 2003).

In spite of this, models of population dynamics are employed as useful tools for assessment of a population's risk of extinction or potential for growth. The use of these models to predict the risk of plant populations is very important in developing effective strategies for conservation of particular plant species. With sensitivity, elasticity, and perturbation analyses, users can assess the impact of changes in demographic rates on a population's growth or decline (Mills \& Lindberg, 2002). Through such analyses the model can be used to assess the impact of management actions, to indicate which variables are most critical for prioritized data collection, and ultimately to guide allocation of conservation resources. There are many examples of models that could contribute to the environmental management practices (Neto et al., 2006; Ouyang et al., 2007; Ouyang, 2008; Kumar et al., 2008; Garedew et al., 2009; Qaiser et al., 2012; Sandker et al., 2012). However, Marrero-Gómez et al. (2007) suggest that models of population dynamics must be used with caution, especially when the results are to be used for decisions on practical species conservation and management.

The tested models, using STELLA, were built on the basis of relationships between analyzed variables. The outcome of a simulation is entirely dependent on these relationships and the input data. Therefore, any output always needs to be analyzed in relation to the input assumptions (Garedew et al., 2012). Stella is well suited for ecological applications, among other reasons because of the clear visualization of the population structure. The software is also valued for the clarity of the density dependent feedback that controls the eventual size of the plant populations. We found the system's dynamics approach useful in modeling the population dynamics of threatened plant species $-P$. patens and commonly occurring taxon $-C$. digitata. The results of the model for $P$. patens proved that it makes a dynamically developing population with the number of individuals growing with time, on disregarding the effects of natural and anthropogenic disturbances. The population of $C$. digitata was found to be dynamically ageing as in both communities studied the number of individuals decreased in the time period considered. The results obtained for $C$. digitata were the response to changes taking place in the two plant communities studied. In the natural oakhornbeam community, the results of ecological observations over the period of 1987-2015 reveal fluctuations in the number of individuals, leading to a relative dynamic equilibrium of $C$. digitata population, ensuring the stability of the phytocenosis. The fluctuations take place at a low number of individuals (65-55) (Łaska, in press) at a low value of death rate. The low birth rate in the
C. digitata population in the natural oak-hornbeam forest habitat is a result of strong interspecies competition in the rich herbal layer.

The changes in the dynamics of vegetation observed over the period of 1987-2003 in the anthropogenically disturbed community (pinetization) are different. The disturbance was the removal of pine and spruce trees from the tree stand. As a result of positive selection, the deciduous species (Carpinus betulus, Corylus avellana) are preferred in the community. The dynamic changes taking place in the forest secondary community observed in 1987 indicated the process of degeneration, while at present the observations imply the process of regeneration, which includes the renewal of the structure and functioning of the community developing towards its natural form. In response to the dynamic development of vegetation in this community the size of $C$. digitata population undergoes rapid changes at a high number of individuals and finally the number of individuals decreased from 378 to 96 plants, which is described by a high death rate.

However, the simulation of $P$. patens population dynamics was performed for a relatively short time (3 years) which is insufficient to answer a wide range of questions about its further fate. The conclusions drawn for $C$. digitata population are more reliable as the model of its population dynamics was constructed on the basis of long-term studies (29 years). The models should be tested using subsequent field data and several scenarios assuming different changes in the number of individuals in populations. Moreover, the model testing would permit verification of the parameters which would ensure correct population functioning. We are currently thinking about expanding the constructed model by adding biotic and abiotic factors affecting the population dynamics, especially the influence of climate change on seasonal variations in the number of $P$. patens individuals, since according to Wójtowicz (2004) a potential threat for this species is climate warming and high instability of thermal conditions in the winter. Similarly in the case of population viability of the narrowly endemic Helianthemum juliae Marrero-Gómez et al. (2007) assumed that herbivores are not a significant factor, because they did not observe any damage that could be attributed to herbivores and all observed deaths in the field were caused by summer drought or natural senescence. One of the most important aspects in these models is the duration of demographic monitoring that is needed to adequately estimate environmental variability.

\section{Conclusions}

Presented models are useful tools in modeling the population dynamics of threatened plant species - P. patens and commonly occurring taxon $-\mathrm{C}$. digitata. The models 
should be tested using subsequent field data and several scenarios assuming different changes in the number of individuals in populations.

\section{Acknowledgements}

We are very much grateful to Prof. Andrzej Nienartowicz Nicolaus Copernicus University in Torun for the providing materials and program STELLA. This research was supported by a grant nr S/WBiIŚ/5/2016 from the Ministry of Science and Higher Education of Poland.

\section{References}

Aloy P. \& Russell R.B., 2004, Taking the mystery out of biological networks. European Molecular Biology Organization Reports 5: 349-350.

Attorre F., De Sanctis M., Farcomeni A., Guillet A., Scepi E., Vitale M., Pella F. \& Fasola M., 2013, The use of spatial ecological modelling as a tool for improving the assessment of geographic range size of threatened species. Journal for Nature Conservation 21: 48-55.

Beissinger S.R. \& McCullough D.R. (eds), 2002, Population viability analysis. The University of Chicago Press, Chicago.

Costanza R. \& Voinov A., 2001, Modeling ecological and economic systems with STELLA: part III. Ecological Modelling 143: 1-7.

Dambacher J.M., Li H.W. \& Rossignol P.A., 2003, Qualitative predictions in model ecosystems. Ecological Modelling 161: 79-93.

Dambacher J.M. \& Ramos-Jiliberto R., 2007, Understanding and predicting effects of modified interactions through a qualitative analysis of community structure. Quarterly Review of Biology 82: 227-250.

Doerr H.M., 1996, STELLA ten years later: a review of the literature. International Journal of Computers for Mathematics Learning 1: 201-224.

European Communities, 2004, Council Directive 92/43/ EEC of 21 May 1992 on the conservation of natural habitats and of wild fauna and flora. Office for Official Publications of the European Communities, Luxembourg.

Falińska K., 2004, Ekologia roślin [Plant ecology]. PWN, Warszawa.

Fang Y., Mauzerall D.L., Liu J., Fiore A.M. \& Horowitz L.W., 2013, Impacts of 21 st century climate change on global air pollution-related premature mortality. Climatic Change 121: 239-253.

Fath B.D., 2004, Network analysis in perspective: comments on "WAND: an ecological network analysis us- er-friendly tool". Environmental Modelling \& Software 19: 341-343.

Forestry Commission Forest Management Plan Supraśl, 01.01.2006-31.12.2015. RDLP, Białystok.

Frank K. \& Wissel C., 2002, A formula for the mean lifetime of metapopulations in heterogeneous landscapes. The American Naturalist 159: 530-552.

Garedew E., Sandewall M., Söderberg U. \& Campbell B., 2009, Land-Use and Land-Cover Dynamics in the Central Rift Valley of Ethiopia. Environmental Management 44: 683- 694.

Garedew E., Sandewall M. \& Söderberg U., 2012, A Dynamic Simulation Model of Land-Use, Population, and Rural Livelihoods in the Central Rift Valley of Ethiopia. Environmental Management 49: 151-162.

Green J.L., Hastings A., Arzberger P., Ayala F.J., Cottingham K.L., Cuddington K., Davis F., Dunne J.A., Fortin M.J., Gerber L. \& Neubert M., 2005, Complexity in ecology and conservation: mathematical, statistical, and computational challenges. BioScience 55: 501-510.

Hannon B. \& Ruth M., 1997, Modelling dynamic biological systems. Springer, New York: 39-43.

High Performance Systems, 2002, Stella technical documentation. High Performance Systems Inc. Hanover, New Hampshire.

Janssen M.A., Bodin Ö., Anderies J.M., Elmqvist T., Ernstson H., McAllister R.R.J., Olsson P. \& Ryan P., 2006, A network perspective on the resilience of social-ecological systems. Ecology and Society 11: 15.

Jensen M., Reynolds K., Langner U. \& Hart M., 2009, Application of Logic and Decision Models in Sustainable Ecosystem Management, [in:] Proceedings of the 42nd Hawaii International Conference on System Sciences. Waikoloa, Hawaii.

Jordán F., 2001, Ecosystem flow networks and community control, [in:] Y. Villacampa, C.A. Brebbia, J.L. Uso (eds), Ecosystems and Sustainable Development III. Advances in Ecological Sciences. WIT Press, Southampton: 771-780.

Jordán F. \& Scheuring I., 2004, Network ecology: topological constraints on ecosystems dynamics. Physics of Life Reviews 1: 139-172.

Journal of Laws, 1996, no. 58, item 263, 264, Convention on the Conservation of European Wildlife and Natural Habitats (Bern Convention). Chancellery of the Prime Minister, Warszawa.

Journal of Laws, 2014, item 1409, Regulation of the Minister of the Environment dated 9 July 2004 on protected species of plants growing wild. Chancellery of the Prime Minister, Warszawa.

Journal of Laws, 2005, no. 94, item 795, Regulation of the Council of Ministers dated 16 May 2005 on types of habitats and plant and animal species in need 
of protection in the form of determining the areas. Chancellery of the Prime Minister, Warszawa.

Kaźmierczakowa R., Zarzycki K. \& Mirek Z., 2014, Polska Czerwona Księga Roślin. Paprotniki i rośliny kwiatowe. Wyd. III uaktualnione i rozszerzone [Polish Red Data Book of Plants. Pteridophytes and flowering plants. Revised and expanded 3rd edition]. Instytut Ochrony Przyrody PAN [Institute of Nature Conservation PAS], Kraków.

Kumar S.V., Peters-Lidard C., Tian Y., Reichle R., Geiger J., Alonge C., Eylander J. \& Houser P., 2008, An integrated hydrologic modeling and data assimilation framework. IEEE Computer 41: 52-59.

Lek S., 2007, Uncertainty in ecological models. Ecological Modelling 207: 1-2.

Leslie H., Ruckelshaus M., Ball I.R., Andelman S. \& Possingham H.P., 2003, Using siting siting algorithms in the design of marine reserve networks. Ecological Applications 13: 185-198.

Li H. \&Wu J., 2006, Uncertainty analysis in ecological studies: an overview, [in:] J. Wu, K.B. Jones, H. Li \& O.L. Loucks (eds), Scaling and Uncertainty Analysis in Ecology: Methods and Applications. SpringerVerlag: 43-64.

Łaska G., 2006, Dynamic tendencies of the secondary communities in the Knyszyńska Forest. Bogucki Wydawnictwo Naukowe, Białystok-Poznań.

Łaska G., 2009, The Natura 2000 network and environmental impact assessment, [in:] G. Laska (ed.), Environmental Protection. Perspective and strategies of the Knyszyńska Forest economic development and nature conservation in Lithuania. Stowarzyszenie Uroczysko, Białystok-Supraśl: 51-68.

Łaska G., 2010, Assessment of the level of threat to vascular flora of the Knyszyńska Forest. Acta Societatis Botanicorum Poloniae 79: 46.

Łaska G., 2012, Changes in the life strategy and adaptation of the reproductive strategy of Carex digitata to disturbances factors. Ecological Questions 16: 9-21.

Łaska G. \& Sienkiewicz A., 2015, Optymalizacja oddziaływania czynników środowiska przyrodniczego w aspekcie odnawiania ekologicznych zasobów środowiska. Inżynieria Ekologiczna 43: 42-48.

Marrero-Gómez M.V., Oostermeijer J.G.B., CarqueAlamo E. \& Banares-Baudet A., 2007, Population viability of the narrow endemic Helianthemum juliae (Cistaceae) in relation to climate variability, Biological Conservation 136: 552-562.

Matuszkiewicz W., 2001, Przewodnik do oznaczania zbiorowisk roślinnych Polski [Guide for the determination pf Polish plant communities]. Wydawnictwo Naukowe PWN, Warszawa.

Mills L.S. \& Lindberg M., 2002, Sensitivity analysis to evaluate the consequences of conservation actions, [in:] S.R. Beissinger \& D.R. McCullough (eds), Population viability analysis. University of Chicago Press, Chicago, Illinois: 338-366.

Morris W.F. \& Doak D.F., 2002, Quantitative conservation biology: theory and practice of population viability analysis. Sinauer Associates, USA.

Naimi N. \& Voinov A., 2012, StellaR: A software to translate Stella models into R open-source environment. Environmental Modelling \& Software 38: 117-118.

Neto A. de C.L., Legey L.F.L., González-Araya M.C. \& Jablonski S., 2006, A System Dynamics Model for the Environmental Management of the Sepetiba Bay Watershed, Brazil. Environmental Management 38: 879-888.

Ouyang Y., Huang C.H., Huang D.Y., Lin D. \& Cui L., 2007, Simulating uptake and transport of TNT by plants using Stella. Chemosphere 69: 1245-1252.

Ouyang Y., 2008, Modeling the mechanisms for uptake and translocation of dioxane in a soil-plant ecosystem with STELLA. Journal of Contaminant Hydrology 95: 17-29.

Özesmi S.L., Tan C.O. \& Özesmi U., 2006, Methodological issues in building, training, and testing artificial neural networks in ecological applications. Ecological Modelling 195: 83-93.

Parviainen M., Luoto M. \& Heikkinen R.K., 2009, The role of local and landscape level productivity in modelling of boreal plant species richness. Ecological Modelling 220: 2690-2701.

Proulx S.R., Promislow D.E.L. \& Phillips P.C., 2005, Network thinking in ecology and evolution. Trends in Ecology \& Evolution 20: 345-353.

Qaiser K., Ahmad S., Johnson W. \& Batista J.R., 2012, Evaluating Water Conservation and Reuse Policies Using a Dynamic Water Balance Model. Environmental Management 51: 449-458.

Raymond B. \& Hosie G., 2009, Network-based exploration and visualisation of ecological data. Ecological Modelling 220: 673-683.

Regan H.M., Colyvan M. \& Burgman M.A., 2002, A taxonomy and treatment of uncertainty for ecology and conservation biology. Ecological Applications 12: 618628.

Regan H.M., Akcakaya H.R., Ferson S., Root K.V., Carroll S. \& Ginzburg L.R., 2003, Treatments of uncertainty and variability in ecological risk assessment of singlespecies populations. Human and Ecological Risk Assessment 9: 889-906.

Reynolds K.M., 2005, Integrated decision support for sustainable forest management in the United States: Fact or fiction? Computers and Electronics in Agriculture 49: 6-23.

Rooney T.P., 2001, Deer impacts on forest ecosystems: a North American perspective. Forestry 74: 201-208. 
Rooney N., McCann K., Gellner G. \& Moore J.C., 2006, Structural asymmetry and the stability of diverse food webs. Nature 442: 265-269.

Sandker M., Ruiz-Perez M. \& Campbell B.M., 2012, Tradeoffs between biodiversity conservation and economic development in five tropical forest landscapes. Environmental Management 50: 633-644.

Uusitalo L., 2007, Advantages and challenges of Bayesian networks in environmental modeling. Ecological Modelling 203: 312-318.

Wintle B.A., McCarthy M.A., Volinsky C.T. \& Kavanagh R.P., 2003, The use of Bayesian model averaging to better represent uncertainty in ecological models. Conservation Biology 17: 1579-1590.

Wójtowicz W., 2004, Pulsatilla patens (L.) Mill. Sasanka otwarta [Pulsatilla patens (L.) Mill. eastern pasqueflower], [in:] H. Werblan-Jakubiec, B. Sudnik-Wójcikowska (eds), Poradnik ochrony siedlisk i gatunków
Natura 2000 [Natura 2000 habitat and species protection guide]. Ministerstwo Środowiska [Ministry of Environment], Warszawa: 168-171.

Wu J., Jones K.B., Li H. \& Loucks O.L. (eds), 2006, Scaling and Uncertainty Analysis in Ecology: Methods and Applications. Springer-Verlag, Printed in the Netherlands.

Zarzycki K., Trzcińska-Tacik H., Różański W., Szeląg Z., Wołek J. \& Korzeniak U., 2002, Ekologiczne liczby wskaźnikowe roślin naczyniowych Polski [Ecological indicators of vascular plants in Poland]. Instytut Botaniki im. W. Szafera, PAN [W. Szafer Institute of Botany, PAS], Kraków.

Zarzycki K. \& Szeląg Z., 2006, Red list of vascular plants in Poland, [in:] Z. Mirek, K. Zarzycki, W. Wojewoda, Z. Szeląg (eds), Red list of plants and fungi in Poland. W. Szafer Institute of Botany, Polish Academy of Sciences, Kraków: 9-20. 